to each of which he has made noteworthy contributions. In the field of protein chemistry he enlarged our knowledge of the phosphoric acid esters present in casein and of the serum glycoproteins; and latterly with his colleague, I. W. Rowlands, he has turned his attention with outstanding success to the important glycoprotein, gonadotrophin of pregnant mares' serum, a problem of great veterinary interest. During his stay in South Africa, Dr. Rimington worked on the constituents of plants poisonous to stock and from this made an incursion with $J$. I. Quin into the photosensitization of animals by phylloerythrin. With P. J. Fourie he discovered the first living cases of congenital porphyria in animals, and this has led to numerous contributions to the porphyrin field of pigment metabolism, on which he is an acknowledged authority. Without doubt Dr. Rimington will be received with welcome at University College Hospital Medical School, for his capacity for collaboration has been a valuable and invariable asset.

\section{Geological Society Awards}

The Council of the Geological Society has made the following awards: Wollaston Medal to Prof. 0 . T. Jones, emeritus professor of geology in the University of Cambridge, for outstanding contributions to knowledge concerning the stratigraphy of Lower Palæozoic sedimentary rocks of Wales; Murchison Medal to Dr. W. Campbell Smith, keeper of minerals in the British Museum (Natural History), for his work on petrology and mineralogy, and his long service as secretary to the Society; Lyell Medal to Dr. L. F. Spath, of the Geological Department of the British Museum (Natural History), who is the foremost expert on the Ammonoidea and on the classification and evolution of the Cephalopoda; Bigsby Medal to Prof. L. R. Wager, of the University of Durham, for his outstanding researches, mainly in petrology, on East Greenland, the Sikkim Himalaya and the north of England; Prestwich Medal to Mr. A. S. Kennard, for his studies of Pleistocene faunas particularly of the non-marine mollusca; Wollaston Fund to Dr. D. R. Grantham, for his work on the Geological Surveys of Tanganyika and British Guiana, especially in the field of mining geology; Murchison Fund to Dr. W. A. Deer, for his researches on rock-forming minerals and petrology, especially of Scottish rocks; and his contribution to the description of the layered intrusion at Kangerdlugssuak in Greenland; one moiety of the Lyell Fund to Mr. A. H. Taitt, of the Anglo-Iranian Oil Company, Ltd., for his work on the exploration for oil in Great Britain, especially on the Nottinghamshire oilfield; another moiety of the Lyell Fund to Dr. F. B. A. Welch, of the Geological Survey of Great Britain, for his additions to our knowledge of the geology of south-west England, both above and below the Mesozoic unconformity, especially in relation to the complicated structures of the Mendips.

\section{Display and Bower Building in Bower Birds}

THE annual cycle of display and bower building by Ptilinorhynchus violaceus Vieill, the satin bower bird, was discussed in Nature, 153, 685 (June 3, 1944), by A. J. Marshall. He stated that this cycle is possibly due to the effect of increasing light and that stimuli from the bower act "through the anterior pituitary" upon the gonads. The selection of coloured decorations by the male matches the epigamic colours of the female and may "serve the function of exciting himself by their resemblance to female colours". It is regrettable that Marshall omitted reference to published work on these lines when mentioning investigations carried out during 1939-41. In "A Contribution to the Biology of the Satin Bower-bird" (Australian Zoologist, 10, 95; 1941), E. Nubling considerably antedates Marshall's conclusions and in some points differs from them. Nubling found that the bower building is not associated with increasing light, for during 1922-26 he found new bowers principally erected in May and June during decreasing light, and states that in such circumstances the whole proceeding of courtship and nidification fall into the period of decreasing light. Regarding the part played by the pituitary body, Nubling wrote (loc. cit., 119), "the role of the pituitary in connection with such sexual manifestations as posturing during display or ceremonial is thus apparently a factor of outstanding importance", and he quoted the opinion of F. H. A. Marshall (1929) that sexual posturing in birds exercises a stimulating influence upon the anterior lobe of the pituitary.

Nubling discussed the selection of colours very fully in 1941, and so long ago as 1924 had submitted conclusions which were published by Dr. Casey A. Wood (Amer. J. Ophthal., 8, 120; 1925), as follows : "Nubling's preliminary experiments made with colored disks . . I I shall now report in his own words. '1. Violet, indigo, blue. Any of these colours is collected by these birds, as well as any hue or tint thereof, without any discrimination. ...2. All the other colours collected correspond to those of the plumage, bill, legs, etc., of the immature male and the fermale, whose plumage is identical. On this I am almost positive, and many comparisons made, using Ridgway's Color Standards for the purpose, have borne out my contention'". Wood points out that the irides of the female are of an even stronger blue than those of her mate. In 1941 Nubling wrote again (loc. cit., 117) that the "decorations are not collected for the sake of their brightness, but for their colours ... they represent the insignia, so to speak, of his female mate. The presence at the bower of objects bearing her colours is then not so much for the purpose of attracting the female, but for his own stimulation; they act on him in the way of an aphrodisiac". Nubling compared the exciting colours with Ridgway's 1912 Colour Guide : it seems that the "lemon-yellow" mentioned by A. J. Marshall is so masked by grey that the resultant effect is erroneously described as lemon-yellow; it corresponds to Ridgway's "deep greyish olive", the colour of the upper surface of the female. This is produced by a structural effect, combined with superposed yellow lipochrome, the black plumage of the male giving a blue structural effect.

\section{Health Problems in War-time}

Brigadier-General J. S. Simmons (Brit. Med. J., 572 , Oct. 28, 1944), speaking at the seventy-third annual convention of the American Health Association at New York on health problems during the past year or so in Italy, Sicily and north-west Europe, said that the public health programme is being carried out by a very small number of American and British medical officers and that it was necessary to rely upon local medical men. The greatest problems so far had been typhoid fever, dysentery, typhus fever, smallpox, malaria, venereal disease and scabies. In Italy and north-west Europe the incidence of typhoid 